\title{
Microstructure and Physical Properties of Alloys for Partial Denture Castings
}

\author{
KAMAL ASGAR and F. C. ALLAN \\ University of Michigan, School of Dentistry, Ann Arbor, Michigan
}

Four types of alloys were investigated from the viewpoint of effect of composition and casting technic on the microstructure and mechanical properties. The microstructures are shown and correlated with the mechanical properties.

Changes in the properties of cobalt-base alloys have been investigated from many points of view, ${ }^{1-4}$ but basic reasons for these changes have not been considered in any depth. Many variables are involved, and the relationships between the variables are closely interconnected. Some of the variables that have been studied are casting technics, ${ }^{1.4}$ amounts of elements present, ${ }^{5,6}$ and investments used. ${ }^{7}$

In this report, various alloys are considered which are used both in dentistry and in industry. A great many alloying agents have been added to the basic Co-Cr combination, and the percentage has been varied within wide limits. However, without corresponding control of the casting technics, the effects of these alloying additions are obscured. In this investigation, the casting procedure was held constant and the microstructures of four alloy types were analyzed from the viewpoint of basic metallurgical considerations such as grain size, occurrence and distribution of carbides and other phases, and reaction to the various etching technics. The mechanical properties of the alloys were obtained also, and their relationship with the microstructure was analyzed.

\section{Materials and Methods}

The basic $60 \%$ cobalt and $25 \%$ chromium alloy, classified as Type I (alloys A* and $\mathrm{B} \dagger$ )

Presented at the 45th General Meeting of the International Association for Dental Research, Miami Beach, Fla, March 16-19, 1966.

This investigation was supported by USPHS Research Grant DE-02017 from the National Institute of Dental Research, National Institutes of Health, Bethesda, Md.

Received for publication October $3,1966$. in this investigation, has been used in dentistry for many years and has had its counterpart in industrial alloys. A whole spectrum of alloys has been developed from this basic composition, each using one or more alloying additions to obtain a particular range of properties. These additions constitute Type II alloys (alloys $C, \ddagger D, \S$ and $E^{\#}$ ). Other entirely different alloys that have promising properties for this application are the stainless steels, classified here as Type III (alloys F\| and GI). Although the constituents and treatment of these alloys are different from those of the first two types considered, their properties are within the range desirable for dental casting alloys. In Type IV replacement-type alloys (alloys $\mathrm{H}^{* *}$ and $\mathrm{I} \dagger \dagger$ ), a major portion of the cobalt is replaced with $\mathrm{Ni}$ or $\mathrm{Fe}$, or both. The resulting compositions are between those of Co-base alloys and of the stainless steels, but casting procedures and microstructure approximate those of the Type I and II alloys. Except for stainless steel, no acceptable heat treatment procedures have been developed for these four types. ${ }^{8}$

Compositions of the alloys studied are given in Table 1 . In some instances, only an indication of the composition could be obtained. For the purpose of comparison, Table 2 presents the properties that are considered representative for these alloys.

The samples were waxed up and invested

* Vitallium, Austenal Dental Division, Howmet Corp., Chicago, III.

$\dagger$ Haynes Stellite 21, Stellite Division, Union Carbide Corp., Kokomo, Ind.

+ Nobilium, Nobilium Products, Inc., Chicago, Ill.

$\S$ Martin experimental alloy, Martin Metals Co., Wheelington, IIl.

\# Ticonium 50, Ticonium Division, CMP Industries, Albany, NY.

II 17-4, Viking Steel Co., Cleveland, Ohio.

IT 17-7, Viking Steel Co,, Cleveland, Ohio.

**: Ticonium 100, Ticonium Division, GMP Industries, Albany, NY.

t† Multimet, Stellite Division, Union Carbide Corp., Kokomo, Ind. 
TABLE 1

Chemical Composition* of the Alloys

\begin{tabular}{|c|c|c|c|c|c|c|c|c|c|}
\hline \multirow[b]{2}{*}{ Elements } & \multicolumn{2}{|c|}{ Type I Alloys } & \multicolumn{3}{|c|}{ Type II Alloys } & \multicolumn{2}{|c|}{ Type III Alloys } & \multicolumn{2}{|c|}{ Type IV Alloys } \\
\hline & A & $\bar{B}$ & $\mathrm{C}$ & $\mathrm{D}$ & $E$ & $\mathrm{~F}$ & $\mathrm{G}$ & $\mathrm{H}$ & I \\
\hline $\mathrm{Cr}$ & 30 & 27.4 & 32.0 & $\mathrm{X} \dagger$ & $20.0-25.0$ & 15.6 & 16.9 & $X$ & $20.0-22.5$ \\
\hline $\mathrm{Co}$ & 62.5 & bal. & 62.0 & $X$ & $20.0-50.0$ & & & & $18.5-21.0$ \\
\hline $\mathrm{Ni}$ & & 2.51 & $\cdots$ & $\ldots$ & $18.0-40.0$ & 4.07 & 7.30 & $X$ & $19.0-21.0$ \\
\hline $\mathrm{Fe}$ & 1.0 & 1.67 & $\cdots$ & $\ldots$ & $\ldots$ & bal. & bal. & & bal. \\
\hline$W$ & & & & & 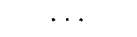 & & & & $2.0-3.0$ \\
\hline $\mathrm{C}$ & 0.5 & 0.27 & 0.35 & $\cdots$ & $\ldots$ & 0.04 & 0.071 & & $0.08-0.16$ \\
\hline $\mathrm{Si}$ & 0.5 & 0.68 & 0.35 & & & 0.50 & 0.32 & & \\
\hline Mo & 5.0 & 5.45 & 5.0 & . & $5-10$ & & & & $2.5-3.5$ \\
\hline $\mathrm{Mn}$ & 0.5 & 0.69 & .. & & $3-6$ & 0.24 & 0.49 & $\ldots$ & $1.0-2.0$ \\
\hline B & $\cdots$ & $<0.001$ & $\cdots$ & $X$ & $\cdots$ & $\cdots$ & $\cdots$ & $\cdots$ & $\cdots$ \\
\hline $\mathrm{Zr}$ & $\ldots$ & $\ldots$ & & $X$ & $\ldots$ & $\ldots$ & $\ldots$ & $\ldots$ & $\ldots$ \\
\hline $\mathrm{Ga}$ & $\ldots$ & $\ldots$ & 0.05 & $\cdots$ & $\ldots$ & $\ldots$ & & & $\cdots$ \\
\hline Al & $\ldots$ & $\ldots$ & $\cdots$ & $\ldots$ & $\ldots$ & & 1.15 & $\mathrm{X}$ & $\ldots$ \\
\hline $\mathbf{P}$ & $\ldots$ & $\ldots$ & $\ldots$ & $\ldots$ & $\ldots$ & 0.013 & 0.018 & $\ldots$ & $\ldots$ \\
\hline S & $\ldots$ & $\ldots$ & $\ldots$ & . & $\cdots$ & 0.016 & 0.007 & . & \\
\hline $\mathrm{Cb}$ & $\ldots$ & $\cdots$ & $\ldots$ & $\ldots$ & $\ldots$ & 0.28 & $\ldots$ & $\ldots$ & 0.75 \\
\hline $\mathrm{Ta}$ & $\ldots$ & $\ldots$ & $\because$ & $\ldots$ & $\cdots$ & 0.01 & $\ldots$ & $\ldots$ & $\int 1.25$ \\
\hline $\mathrm{Cu}$ & $\cdots$ & $\cdots$ & 0.04 & $\cdots$ & $3.0-6.0$ & 3.24 & $\cdots$ & $\cdots$ & \\
\hline N & $\cdots$ & $\cdots$ & $\cdots$ & $\cdots$ & & $\cdots$ & $\cdots$ & $\cdots$ & $0.1-0.2$ \\
\hline $\mathrm{Be}$ & $\ldots$ & $\ldots$ & $\ldots$ & $\ldots$ & $0.5-1.0$ & $\ldots$ & $\ldots$ & $\ldots$ & 0.1 \\
\hline
\end{tabular}

* Information on compositions was obtained as follows: alloy A, US Patent No. 2,180,549; alloy B, certified chemical analysis of remelt shot as received, Stellite Division, Union Carbide Corp.; alloy C. US Patent No, 3,134,670 and personal communications; alloy D, personal communication; alloy E., U.S. Patent No. 2,631,095; alloys $\mathrm{F}$ and G. certified chemical analyses of wire as received, Viking Steel Co.; alloy H, personal communication; alloy I, brochure. Stellite Division, Lnion Carbide Corp., Sept 1966, p 7.

$\dagger X$, element known to be present in alloy.

TABLE 2

Mechanical Properties of Alloys Under Standard Casting Conditions AS REPORTED IN THE LiTERATURE*

\begin{tabular}{|c|c|c|c|}
\hline Alloy & $\begin{array}{l}\text { Tensile Strength } \\
\text { (psi) }\end{array}$ & $\begin{array}{l}\text { Yield Strength } \\
\text { (psi) }\end{array}$ & Elongation \\
\hline \multicolumn{4}{|l|}{ Type I } \\
\hline A & 97,000 & 58,000 & $4.0-6.0$ \\
\hline B & 103,000 & 82,000 & 8.0 \\
\hline \multicolumn{4}{|l|}{ Type II } \\
\hline C & 168,000 & 88,000 & 3.8 \\
\hline $\mathrm{E}$ & 105,000 & 63,000 & $4.0-9.3$ \\
\hline \multicolumn{4}{|l|}{ Type $I I I$} \\
\hline $\mathrm{F}$ & 193,000 & 192,000 & 21.4 \\
\hline $\mathrm{G}$ & 199,000 & 188,000 & 16.3 \\
\hline \multicolumn{4}{|l|}{ Type IV } \\
\hline $\mathrm{H}$ & 140,000 & & 3.5 \\
\hline I & 98,000 & $\begin{array}{c}57,800 \\
\text { (at } 0.2 \% \text { off-set) }\end{array}$ & 27.0 (in/in) \\
\hline
\end{tabular}

* Alloy A, S. H. Bush, C. E. Ingersoll, and F. A. Peyton, prepublication report, University of Michigan; alloy B, Engineering Alloys Digest, Inc., May 1953, revised Nov. 1960; alloy C, R. Earnshaw, Brit Dent J, 101:67-75, 1956; alloy D, experimental alloy-no data available; alloy E, certified properties of wire as received, Viking Steel Co.; alloy $\mathrm{F}$, personal communication; alloy $\mathrm{G}$, personal communication; alloy $\mathrm{H}$, personal communication; alloy I, brochure, Stellite Division, Union Carbide Corp., Sept 1966, p 7.

according to ADA Specification No. $14,{ }^{9}$ with the following exceptions. The samples were positioned to act as sprues instead of vents (Fig 1). The standard casting procedure was to air cast the alloys into silicate molds that had been burned out at 1,600F (871.1C).
However, alloy $\mathrm{H}$ (Type IV) was cast into calcium sulfate-bonded investment that had been burned out at 1,300F (704.4C). The casting temperature was judged visually and approximated the normal melting temperature. In addition to being air cast, alloy $\mathrm{A}$ 


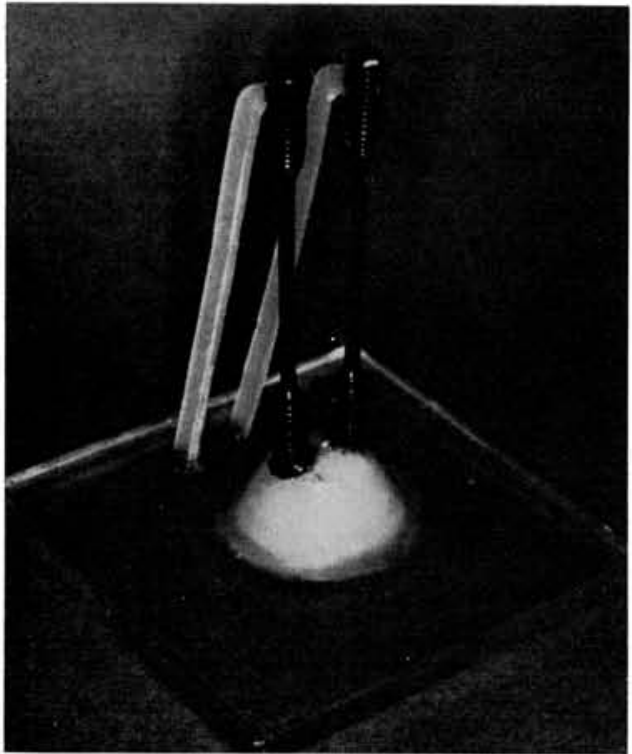

FIG 1.-Method of spruing.

(Type I) samples also were cast under an argon atmosphere.

The surface condition of the as-cast samples was noted and the samples were cleaned and prepared for mechanical testing. A machine* was used to determine the ultimate tensile strength, the one-tenth percent yield strength, and the elongation values of the samples. The values for the mechanical properties were tabulated and analyzed by computer.

After testing, the broken samples were prepared for metallographic examination. Two sections of each test bar were prepared, one of the cross section immediately adjacent to the fracture point and the other of a longitudinal section. These were mounted in a cold-setting plastic $\dagger$ and polished according to standard metallographic procedure and using silicon carbide during the fine grinding stage and levigated alumina on the polishing wheels. Samples were etched according to the procedure outlined (Table 3 ), and the resulting microstructures were studied from the viewpoint of the distribution of carbides and the appearance of other phases. Then the microstructure was compared with the corresponding mechanical properties.

* Riehle Testing Machine, American Machine and Metals, Inc., East Moline, III.

$\dagger$ Castolite, Buehler Ltd., Evanston, III.
TABLE 3

EtChing Procedures

\begin{tabular}{|c|c|c|c|}
\hline Alloy & $\begin{array}{l}\text { Composition } \\
\text { of Etching } \\
\text { Reagents }\end{array}$ & $\begin{array}{l}\text { Time } \\
\text { (sec) }\end{array}$ & Comment \\
\hline \multicolumn{4}{|l|}{ Type I } \\
\hline A & $\begin{array}{l}5 \% \mathrm{HCl}, \\
\text { electrolytic* }\end{array}$ & $1-5$ & $\begin{array}{l}\text { Use two dry cells in } \\
\text { series; specimen } \\
\text { anode, carbon } \\
\text { cathode }\end{array}$ \\
\hline B & $\begin{array}{l}\text { Same as for } \\
\text { alloy A }\end{array}$ & & \\
\hline \multicolumn{4}{|c|}{ Type II } \\
\hline C & $\begin{array}{l}\text { Same as for } \\
\text { alloy A }\end{array}$ & & \\
\hline D & $\begin{array}{l}60 \mathrm{ml} \mathrm{HCl}^{\mathrm{HCl}} \\
15 \mathrm{ml} \mathrm{HNO}_{3} \\
15 \mathrm{ml}^{2} \text { acetic } \\
\text { acid } \\
15 \mathrm{ml} \text { water } \dagger\end{array}$ & $1-5$ & $\begin{array}{l}\text { Solution must be } \\
\text { aged at least } 1 \text { hour } \\
\text { before use } f\end{array}$ \\
\hline $\mathrm{E}$ & $\begin{array}{l}\text { Unable to } \\
\text { etch } \$\end{array}$ & & \\
\hline \multicolumn{4}{|c|}{ Type III } \\
\hline a & $\begin{array}{l}10 \% \text { oxalic } \\
\text { acid, electro- } \\
\text { lytic\# }\end{array}$ & $10-15$ & $\begin{array}{l}\text { Six volts recom- } \\
\text { mended }\end{array}$ \\
\hline G & $\begin{array}{l}\text { Same as } \\
\text { alloy F }\end{array}$ & & \\
\hline \multicolumn{4}{|c|}{ Type IV } \\
\hline $\mathrm{H}$ & $\begin{array}{l}5 \mathrm{ml} \text { of } 130 \\
\text { volume } \mathrm{H}_{2} \mathrm{O}_{2} \\
\text { and } 100 \mathrm{ml} \\
\mathrm{HCl} \text { concen- } \\
\text { trated }\end{array}$ & $1-5$ & $\begin{array}{l}\text { Keep solution cool } \\
\text { to avoid over-etch- } \\
\text { ing }\end{array}$ \\
\hline 1 & $\begin{array}{l}\text { Same as for } \\
\text { alloy A }\end{array}$ & & \\
\hline
\end{tabular}

* Metallographic Etching Reagents for Cobalt and CobaltContaining Alloys, Cobalt Information Center, 1956.

t Personal communication with Martin Metals Company. $¥$ Swab sample with fresh portion from stock solution each time.

$\$$ A mong the etching reagent tried were: $5 \% \mathrm{HCl}$ electrolytic; $2 \%$ chromic acid electrolytic; $30 \% \mathrm{H}_{2} \mathrm{O}_{2}, \mathrm{HCl}$; heat tint.

G. L. Kehl: Metallographic Laboratory Practice, ed 3, $949, \mathrm{p} 413$

II Personal communication with Ticonium Company.

\section{Results}

The mechanical properties that were determined for the four types of alloys are shown in addition to the number of samples cast, the number of points that were usable in the analysis, and the mean and standard deviation for each of the mechanical properties (Table 4). For a point to be usable, the value of each property must have been within the $98 \%$ confidence interval range.*

A representative microstructure was selected for each alloy. Since the samples were in the shape of test bars, the microstructure

* The 98\% confidence interval range is defined for a group of samples as the mean of the group plus and minus the $t$ value for the group times the standard deviation of the group. 
TABLE 4

Mechanical Properties and Approximate Grain Sizes of the Alloys Tested

\begin{tabular}{|c|c|c|c|c|c|c|c|c|c|}
\hline \multirow[b]{2}{*}{ Alloy } & \multirow{2}{*}{$\begin{array}{l}\text { Total No. } \\
\text { of Samples } \\
\text { Cast }\end{array}$} & \multirow{2}{*}{$\begin{array}{l}\text { No. Points } \\
\text { Usable in } \\
\text { Analysis }\end{array}$} & \multicolumn{2}{|c|}{ l'rs (psi) } & \multicolumn{2}{|c|}{$0.1 \%$ Yield (psi) } & \multicolumn{2}{|c|}{$\begin{array}{c}\text { Elongation } \\
(\%)\end{array}$} & \multirow{2}{*}{$\begin{array}{c}\text { Grain } \\
\text { Size } \\
\text { (ASTM } \\
\text { No.*) }\end{array}$} \\
\hline & & & $\bar{x}$ & $\sigma$ & $\overline{\mathrm{x}}$ & $\sigma$ & $\bar{x}$ & $\sigma$ & \\
\hline \multicolumn{10}{|l|}{ Type I } \\
\hline \multicolumn{10}{|l|}{ Alloy A } \\
\hline Air & 8 & 4 & 79,500 & 2,600 & 63,600 & 12,600 & 2.0 & 1.5 & -3 or \\
\hline $\begin{array}{c}\text { Argon } \\
\text { Alloy B }\end{array}$ & 13 & 11 & $\begin{array}{l}88,900 \\
93,200\end{array}$ & $\begin{array}{l}7,700 \\
7,000\end{array}$ & $\begin{array}{l}73,900 \\
71,800\end{array}$ & $\begin{array}{l}4,100 \\
3,700\end{array}$ & 2.0 & $\begin{array}{l}0.9 \\
0.7\end{array}$ & over \\
\hline \multicolumn{10}{|l|}{ Type II } \\
\hline Alloy C & 16 & 6 & 114,300 & 17,000 & 80,000 & 6,500 & 1.6 & 0.0 & -2 \\
\hline Alloy D & 14 & 12 & 61,600 & 12,800 & 41,800 & 2,300 & 7.4 & 3.8 & -1 \\
\hline Alloy E & 8 & 5 & 92,000 & 5,700 & 82,000 & 7,500 & 0.5 & 0.9 & $\ldots$ \\
\hline \multicolumn{10}{|l|}{ Type III } \\
\hline Alloy $\mathrm{F}$ & 22 & 17 & 123,000 & 13,300 & 80,700 & 8,400 & 0.8 & 0.6 & 1,2 \\
\hline Alloy G & 15 & 14 & 85,400 & 21,400 & 26,900 & 3,300 & 5.9 & 1.8 & 5 \\
\hline \multicolumn{10}{|l|}{ Type IV } \\
\hline $\begin{array}{l}\text { Alloy H } \\
\text { Alloy I }\end{array}$ & 10 & 9 & 117,200 & 8,300 & 102,800 & 4,100 & 2.4 & 1.7 & 0 \\
\hline Alloy I & 17 & 13 & 46,200 & 11,100 & 35,400 & 6,400 & 1.6 & 2.3 & 0 \\
\hline
\end{tabular}

*From ASM Metals Hanabook, 1948, p 405 .

was not identical with that found in the actual dental casting. However, because a uniform and reproducible shape must be used for comparing properties, low magnification was chosen to give an idea of the grain size and high magnification to give the detail of the phases. Since the grain size varied within each alloy, the determination of the size was approximate (Table 4). In general, except for the stainless steel alloys, the grain size was large for each alloy.

Figure 2 shows the microstructures of the Type I alloys. Figure 3 shows the microstructures of the Type II alloys. Alloy $\mathrm{H}$ could not be etched suitably with any known etching reagent, so the microstructure could not be compared with the others (Fig 3f). The microstructures of the Type III alloys are shown (Fig 4). The only characteristic compared was the grain size, which was smaller than that of the $\mathrm{Co}-\mathrm{Cr}$ alloys. Both of these alloys were tested in the as-cast condition, whereas normally they would be heat-treated. The microstructures of the Type IV alloys are shown (Fig 5). Care had to be taken in etching alloy $\mathrm{H}$, or artifacts (Fig $5 c$ ) would give a misleading microstructure.

\section{Discussion}

The purpose of this investigation was to survey a number of alloys that possibly could be used for making partial denture castings. The casting technic was held as nearly constant as possible to give a base for further evaluation. For this reason, the mechanical properties varied (considerably in some instances) from the values usually reported. In industrial practice, each alloy is cast to give optimum properties; the melting time, atmosphere, and casting technic vary for each alloy. The form of the sample also varies, as does the testing procedure. A comparison of data (Tables 2, 4) demonstrates the influence of the casting technic and the various aspects of testing on the properties of the finished casting.

Columns 2 and 3 in Table 4 show the castability of each alloy for the specified procedure. For some alloys, such as alloys $\mathrm{G}$ and $\mathrm{H}$, the proportion is high. For others, such as alloy $C$, the proportion of usable casting points is quite low. A comparison of the results for alloy $\mathrm{A}$, cast in an air or an inert (argon) atmosphere, shows the dependence of the results on variables in the procedure.

In Type I alloys, the microstructure of the alloy A samples shows that the grains are large and that the carbides are large and dispersed. For alloy B, the grain size is also large; however, the carbides are much smaller. In Figure $2 c$, the pearlite is shown to be precipitated at the grain boundary. The presence of massive carbides (pearlite) lowers the ductility of the alloy.

The values for elongation in this type of alloy are higher in Table 2 than in Table 4. Asgar et $a^{10}$ have shown the effect of casting temperatures on carbide distribution. Casting at higher temperatures would result in the 

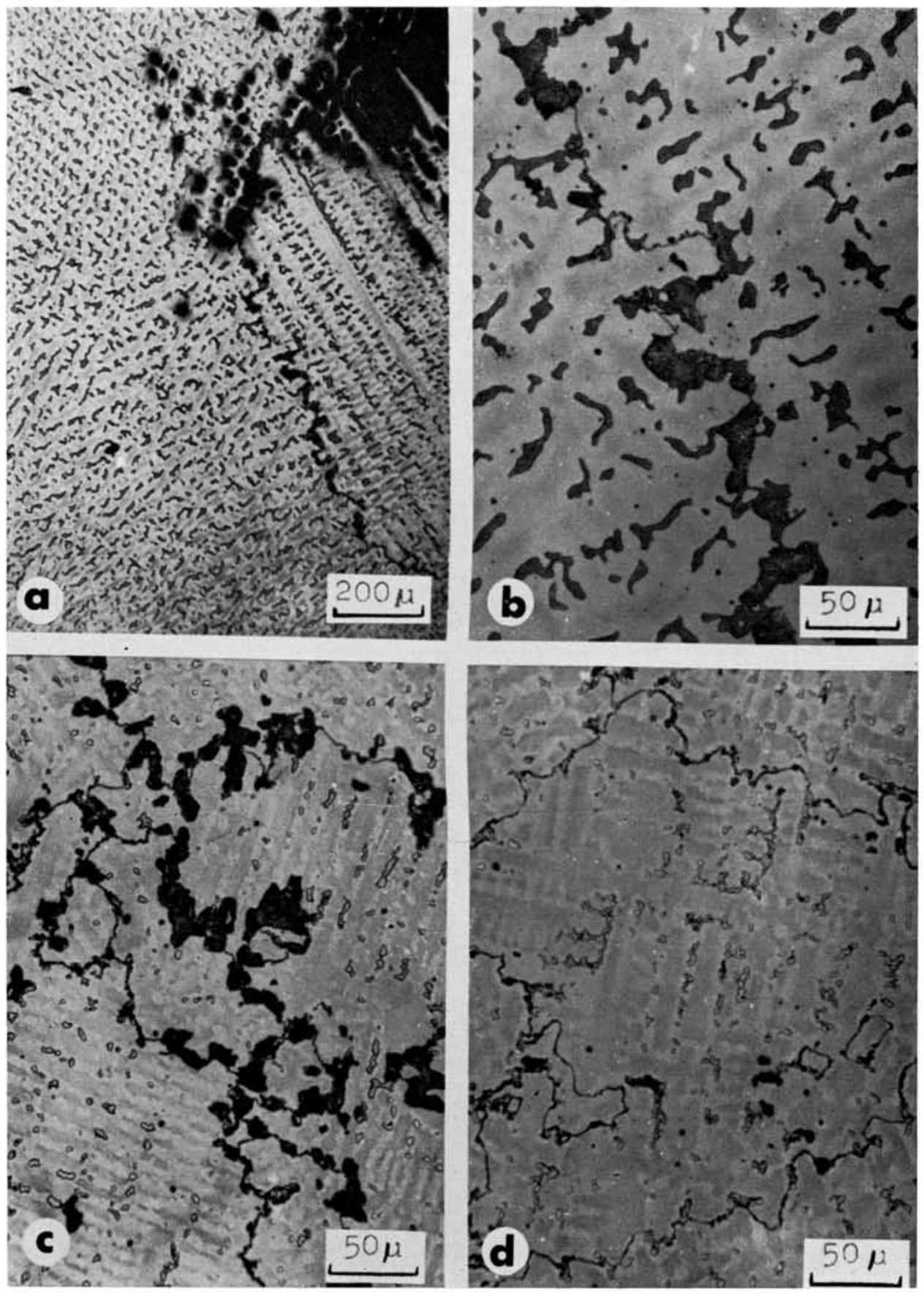

FIG 2.-Microstructures of Type I alloys. $a$, Alloy A (orig mag $\times 60)$. $b$, Same areas as in $a$ (orig mag $\times 240$ ). $c$, Alloy B showing high pearlite (orig mag $\times 240$ ), $d$, Alloy B showing low pearlite (orig mag $\times 240$ ). 

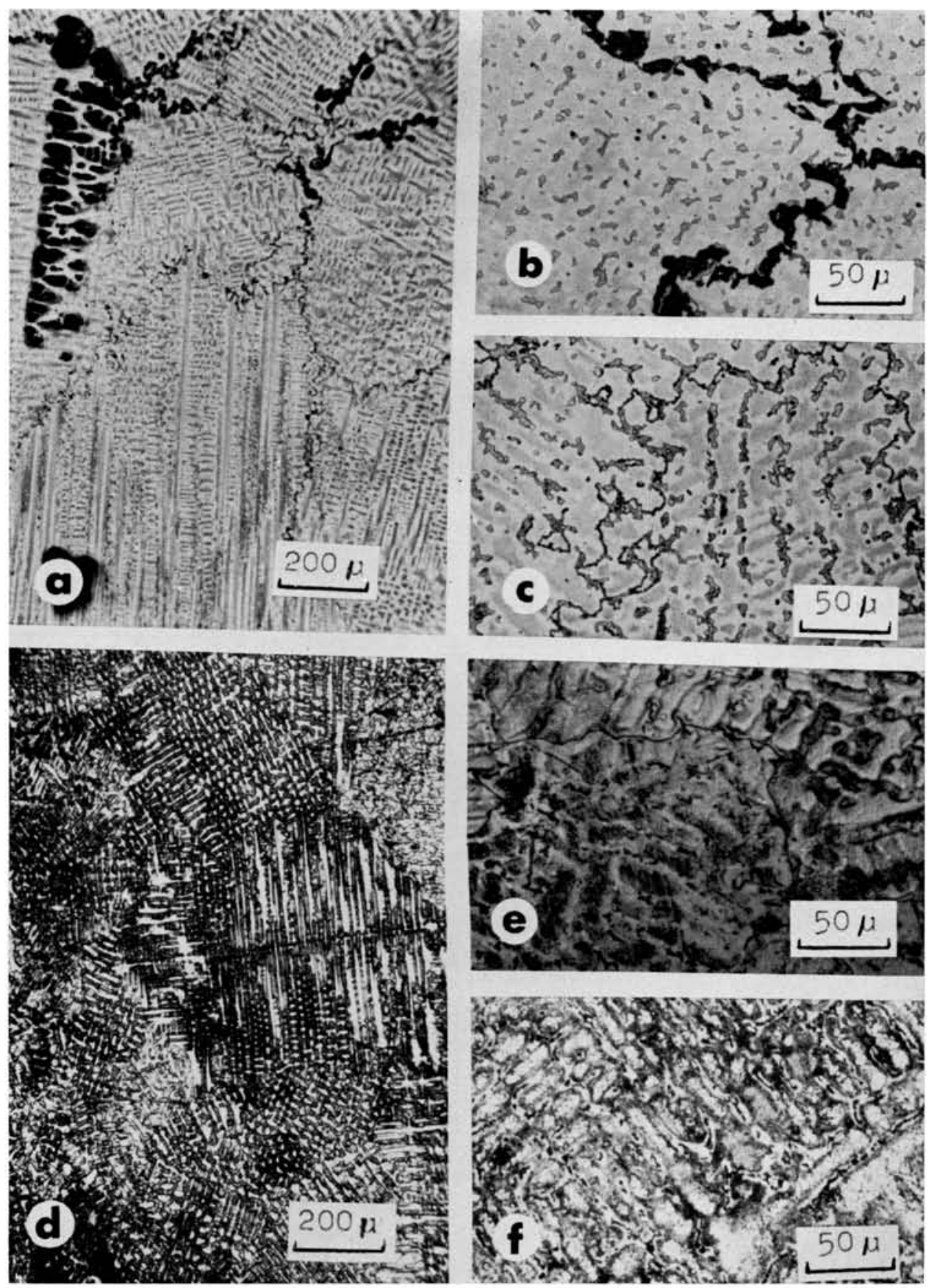

FIG 3.-Microstructures of Type II alloys. $a$, Alloy $\mathrm{C}$ (orig mag $\times 60$ ). $b$, Alloy $\mathrm{C}$ showing high pearlite (orig mag $\times 240$ ). $c$, Alloy $\mathrm{C}$ showing low pearlite (orig mag $\times 240$ ). $d$, Alloy D (orig mag $\times 60$ ). $e$, Higher magnification of alloy D (orig mag $\times 240)$. $f$, Alloy E (orig mag $\times 240$ ). 

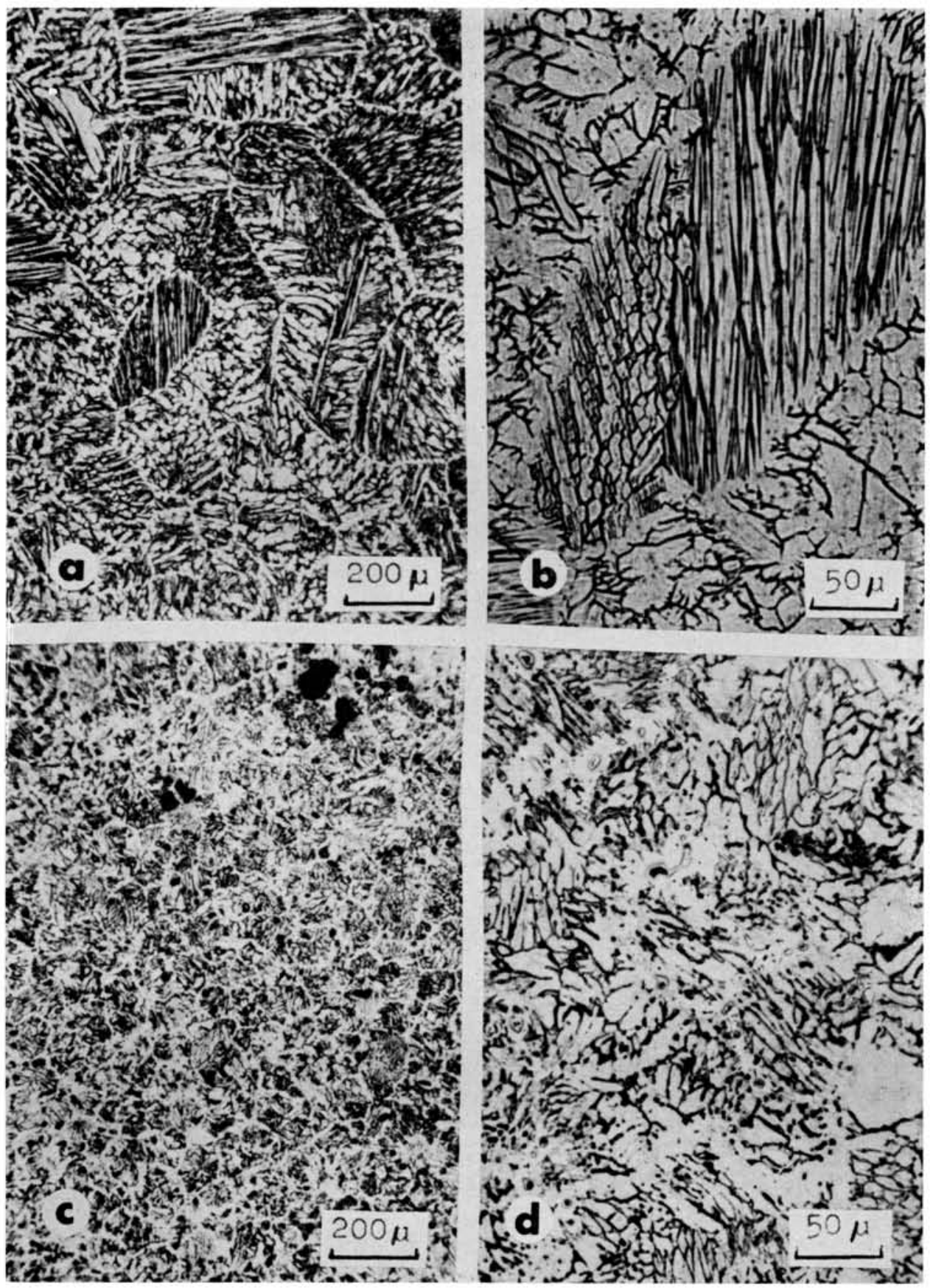

FIg 4.-Microstructure of Type III alloys. $a$, Alloy $\mathrm{F}$ (orig mag $\times 60$ ). $b$, Same area as in $a$ (orig mag $\times 240)$. $c$, Alloy $\mathrm{G}$ (orig mag $\times 60)$, $d$, Same area as in $c$ (orig mag $\times 240$ ). 

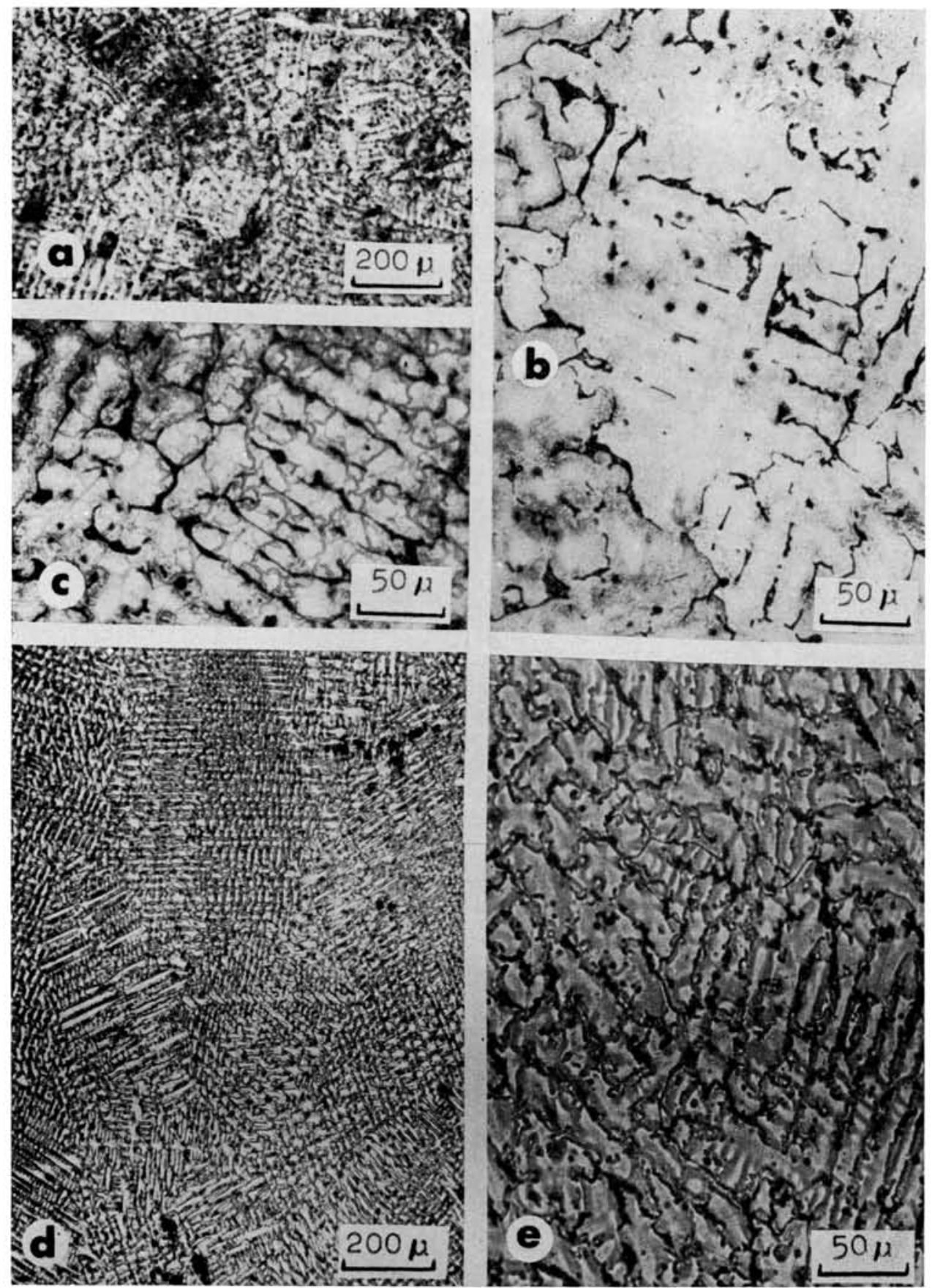

Fig 5.-Microstructures of Type IV alloys. $a$, Alloy $\mathrm{H}$ (orig mag $\times 60$ ). $b$, Alloy $\mathrm{H}$ showing grain boundaries (orig mag $\times 240$ ). $c$, Alloy $\mathrm{H}$ showing substructure (orig mag $\times 240$ ). $d$, Alloy I (orig mag $\times 60$ ). $e$, Alloy I (orig mag $\times 240$ ). 
dispersion of the massive carbides seen in Figures $2 c$ and $3 b$.

In the Type II alloys, the effects of the alloying additions on the general microstructure typified in the Type I alloys were demonstrated. Alloy C (Fig 3a-c) had smaller grain size than alloy $A$, which was probably due to the addition of gallium. Gallium, which has a low melting point, made the cooling rate more critical in this alloy.

In the experimental alloy, $\mathrm{D}$, the addition of zirconium and boron raised the melting temperature of the alloy, which caused carbides to be dispersed and distributed within the grain rather than precipitated at the boundaries. The elongation values were considerably higher for alloy $\mathrm{D}$ due to the addition of these elements; however, the tensile strengths were the lowest of all the alloys tested. Again, the grain size was smaller than that of the Type I alloys. Alloy D was quite soft; consequently, polishing was difficult because the surface tended to smear. Etching of the alloy therefore also was difficult, and the resultant microstructure was harder to interpret.

Alloy E, which had beryllium as an additive, had values similar to, although lower than, those of alloy $D$.

The microstructure of Type III alloys (Fig 4) was a different type. The elongation values of alloy $G$ were much higher than those of alloy $F$, although the tensile strength was much higher for alloy $F$.

In alloy $\mathrm{H}$, cobalt was replaced by nickel and a small amount of aluminum is added, and the mechanical properties were thereby improved. In contrast to an earlier version (alloy E), this alloy is etchable.

Although the composition of alloy I was intermediate to the basic $\mathrm{Co}-\mathrm{Cr}$ alloys and the stainless steels, the microstructure resembled that of the Co-Cr alloys. Here, again, the alloy etching was similar to that of alloy $\mathrm{D}$ (Fig $3 e, 5 e$ ). By the method used, the properties of alloy I were poor.

The microstructures of some of these alloys have not been discussed in the literature. The etching technics are critical. A great deal of effort was spent trying to determine the mi- crostructure of alloy $\mathrm{E}$, but microstructure that seemed representative of the alloy was not found.

\section{Conclusions}

Preliminary results show that a wide range of alloys can be considered for making partial denture castings. The grain size of all the alloys was large. The microstructure varied, and these differences correlated with differences in the mechanical properties. In some instances, these properties were not the same as those reported by the manufacturers and by other sources, because the casting technic was not optimum for each alloy. Further work is planned to determine which variables in the casting procedure are significant and which alloys can most easily be adapted to a dental procedure.

\section{References}

1. Asgar, K., and Peyton, F.A.: Effect of Casting Conditions on Some Mechanical Properties of Cobalt-Base Alloys, $J$ Dent Res 40:73-86, 1961.

2. Harcourt, H.J.: Fracture of Co-Cr Castings, Brit Dent J 110:43-50, 1961.

3. Riddihough, M.: Properties of Co-Base Investment-Cast Alloys, Foundry Trade J 106: 421-428, 1959.

4. Dunlop, A.: Vacuum Investment Casting, Metal Indust 96:169-173, 1960.

5. Freche, J.C.; Ashbrook, R.L.; and SANDROCK, G.D.: Further Investigation of HighTemperature Cobalt-Tungsten Alloys for Aerospace Application, Cobalt 24:125-127, 1964.

6. LOBL, K.; JEZEK, J.; and TUMA, H.: Influence de Quelques Éléments sur la Stabilité du Stellite, Rev Metallurgie 56:324-330, 1959.

7. Allan, F.C., and Asgar, K.: Reaction of $\mathrm{Co}-\mathrm{Cr}$ Casting Alloys with Investment, $J$ Dent Res 45:1516-1528, 1966.

8. WLODEK, S.T.: Embrittlement of $\mathrm{Co}-\mathrm{Cr}-\mathrm{W}$ (L-605) Alloy, ASM Trans 56:287-303, 1963.

9. Guide to Dental Materials, ed 2, Chicago: American Dental Association, 1964, p 123.

10. Asgar, K., and Peyton, F.A.: Effect of Microstructure on the Physical Properties of Cobalt-Base Alloys, $J$ Dent Res 40:63-72, 1961. 